\title{
The Effect of Class-Wide Enrichment Applied to Gifted and Normal Children in Early Childhood
}

\author{
Hatice Darga* \\ Mehmet Akif Ersoy University, Bucak Health Academy, Department of Child Development, \\ Burdur, Turkey \\ ORCID: 0000-0001-6759-6660
}

\author{
Ayşegül Ataman \\ Lefke Avrupa University, Faculty of Education Lefke/Northern Cyprus
}

ORCID: 0000-0002-5566-6606

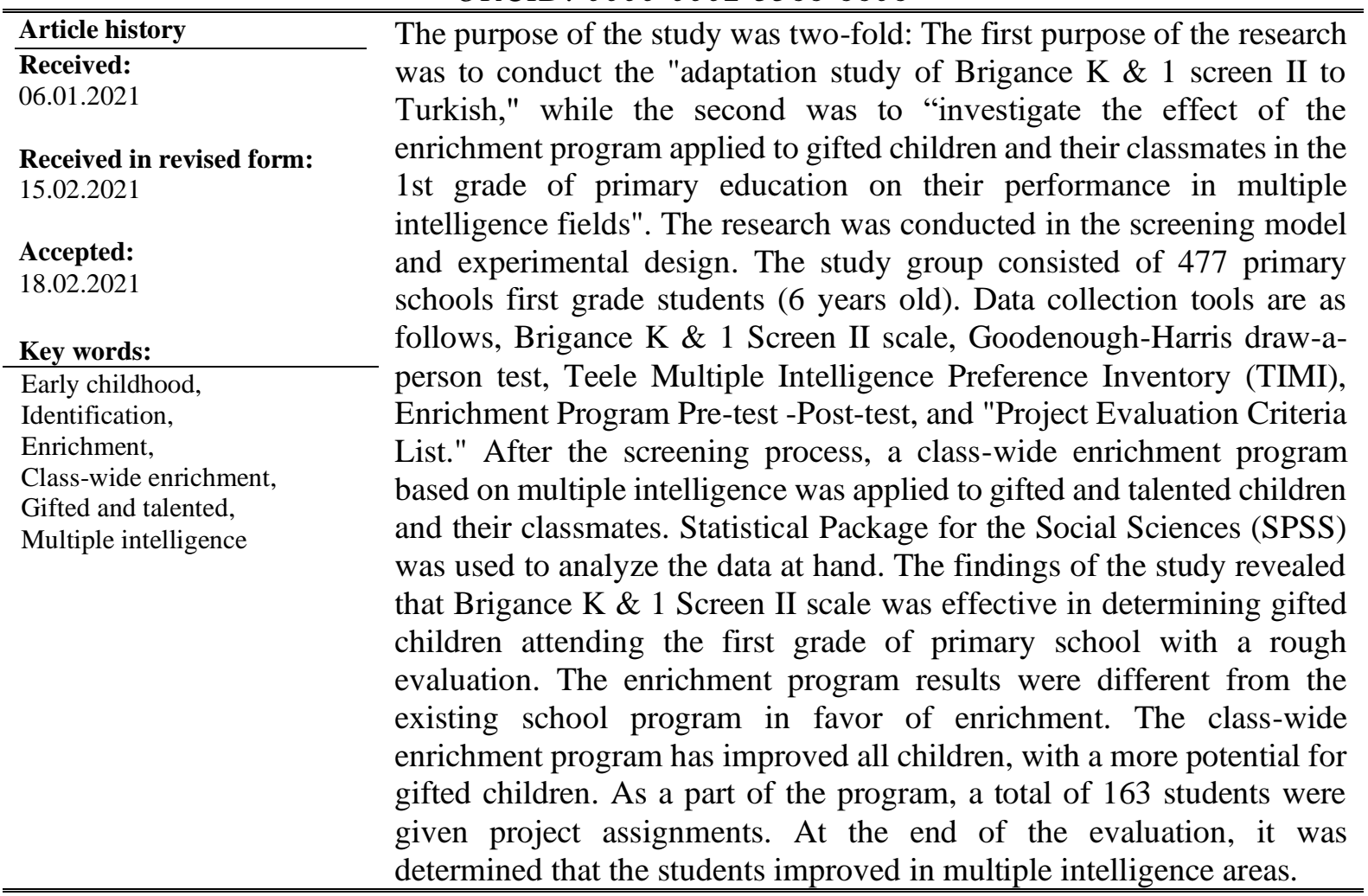

\section{Introduction}

While education enables individuals to develop by revealing their intelligence and abilities, it can be considered as a vital tool that will increase the development level of the society they live in. The main goal of education is to provide educational services suitable for the different needs of children who are developing differently, as well as for normally developing children. Gifted children develop rapidly and learn very quickly, unlike other

\footnotetext{
*Correspondency: hdarga@hotmail.com
} 
groups that need special needs as well as their normally developing peers. It should be considered that these children have extraordinary sensitivity and cannot reach their potential without special efforts (Enç, 2004, 2005).

Researchers claimed that all gifted groups, from being gifted in a field to rare examples of the so-called genius, did not form a homogenous group, but differed in each field and category (Turnbull \& Turnbull, Shank, Smith, Leal, 2002). In the U.S. Maryland report (1972), giftedness, general mental ability, specific academic ability, creative or productive thinking ability, leadership ability, and visual and performing arts skills high-level performance and success in one or more of these talent areas (Culatta \& Tompkins, 1999; Ataman, 1984; 2003; 2004; 2009; Smutny et al. 1997; Turnbull \& Turnbull, Shank, Smith, Leal, 2002),

According to the theory of multiple intelligences (Gardner, 1999), intelligence; is the ability to create a product or problem solving that is valuable to one or more cultures. Intelligence, which is a biological and psychological potential, can be developed, is versatile, and presents a whole. There are 8 special intelligences in different cultures and societies, and each individual has these intelligences at different levels. These multiple intelligences are as follows: verballinguistic intelligence, logical/mathematical intelligence, visual-spatial intelligence, physical kinesthetic intelligence, music intelligence, interpersonal - social intelligence, internal-self intelligence, and naturalist intelligence. Individuals who have talent in a particular field often exhibit both talent and creativity in the same field. While talent symbolizes technical skills and knowledge in that field, creativity is unexpected and unique products in that field (Gardner, 1999).

According to studies individuals' learning by using their intelligence has occurred in different periods and in different ways, and it is claimed that learning in the field of verbal-language intelligence is more effective from kindergarten to third grade. In the next process, its usage decreases. On the other hand, logic-mathematical intelligence is the most effective for grades 1- 4. That said, visual-spatial intelligence and physical- kinesthetic intelligence are effective throughout the first phase of primary education. As a result, addressing the first stage of primary education ( $1-5$. grade) is considered the most accurate approach for transmitting information through visual and active learning. Given these characteristics, Gardner (1999) says that children should be encouraged to experience in a wide range of areas in the first seven years of their lives. In the next seven years, they should acquire knowledge that is compatible with some basic skills, literacy, and culture. In addition Gardner (1999) emphasizes, the importance of starting to specialize in an art field, a physical field, and an academic field, as they want to explore the sense of mastery of a subject and the comprehend the importance of their experience in-depth.

Early and accurate diagnosis is required for an appropriate educational environment. (Turnbull \& Turnbull, Shank, Smith, Leal, 2002). The most important time to discover gifted and talented children is early childhood (Ataman, 2009). Identifying gifted areas of children in early childhood, which includes preschool and first two years of primary education (Dağlığlu, 1995; 2002, Gür, 2006), is critical for providing an appropriate and suitable education environment.

In general, early childhood diagnostic tools make it only possible for the child to be diagnosed in cognitive and mental terms when he or she is six years old (Turnbull et al., 2002). The obstacles to the program and early recognition of students with special and superior abilities are educational policies that do not agree to take them to the next level of their peers (Hallahan \& Kauffman, 2003). 
It is particularly emphasized that the use of more than one criterion for the placement of resources in diagnosis and training programs is necessary for accurate and adequate diagnosis (Hallahan \& Kauffman, 2003; Bildiren, 2016; Saranl1, Er \& Deniz, 2017). According to The National Association for Gifted (in USA) Children, the use of valid indicators from multiple criteria and sources is the best practice, considering the limitations of the tests (Moon \& Rosselli, 2002). Moon (1995) claimed that all diagnostic methods should be intended to determine both early development and the ability to represent the potential (Heward, 2000).

In studies conducted in several countries, discussions on the recognition of gifted children only with scales and appropriate forms of education have been continuing, and it is emphasized that the diagnosis continues with these scales, but at least the use of multiple criteria is healthier (Williams, 2002; Walker, 2005; Wheeler, 2006).

Teaching objectives that meet the gifted students' special needs and define their characteristics; balancing the learning speed of the student with the speed of teaching; ensuring the level and depth of the subject to be correlated with the student's level of ability and knowledge; linking teaching with the student's interests (Turnbull et al., 2002) are all fundamental steps in the process in this regard. The problem with planning is not to do something, but deciding on what is the best thing to do. The point to keep in mind is that they are not deprived of activities they would want more.

While planning education programs for gifted students, the developmental needs of the age group that constitute the target populace of the program should be carefully considered. The response to a child's readiness to learn is of great importance for philosophy, which determines the qualities of environments that are considered as the most appropriate learning environments for working with developmentally advanced young children (Moon \& Rosselli, 2002).

It is observed that various program implementation methods continue to be used in teaching. Three approaches used in the education of gifted and talented children; acceleration is the compression of the curriculum and enrichment (Heward, 2000). As a result of existing diagnostic and program implementation studies, curriculum development and differentiation studies, such as enrichment and acceleration are useful for all students in upper, middle, and lower levels, as well as for school-wide enrichment, which will include students who are successful and normal except for the gifted students. It is concluded that the studies have achieved high success (Rogers, 1991; Brumbaugh, 1994; Witte, 1994; Tassel-Baska, 2002; Williams, 2002; Wheeler, 2006; Morgan, 2007; Field, 2009; Reis \& Renzulli, 2009).

Enrichment programs rather than speed should be implemented to meet the instructional needs of exceptionally talented students. Enrichment programs enhance the ability to understand programs and help especially gifted students. Such teaching supports students' level of talent and high-level knowledge with in-depth subject content (Turnbull et al., 2002). A well-designed program, the identification processes, the objectives, and the format need to be defined. Planning and implementing a program for giftedness require the change of existing educational systems, beliefs, and structures (Moon \& Rosselli, 2002).

Program enrichment is one of the most applied methods in the world, enabling gifted and talented children to receive education among their normally developing peers and to be supported with in-depth studies in the field where they are superior (Smutny et al., 1997; Hallahan \& Kauffman, 2003). Enrichment programs in Turkey since 1968 and the program has been implemented in a limited and intermittent manner vertically and horizontally (Ataman, 
2003; 2004; 2009). Science and Art Education Centers (BİLSEM), which the Ministry of National Education started to open in 2002, are implementing an enrichment program. The number of these centers that students attend outside of school has reached 138 in 2019. The increase in the number of centers and their service up to the 2nd grade level have led to an increase in research in a parallel fashion.

Enrichment applied horizontally and vertically, semi-day programs, special courses, private teachers, independent studies, field trips, and student exchange programs can be enriched (Davasligil, 1995; 2004; Şahin, 1996; Ataman, 1984; 2003; 2004; 2009; Tekbas, 2004; Enç, 2005). Activities and course types are increased in horizontal enrichment. In other words, if there are seven different courses in the normal class, one or two courses are added to these courses for the gifted students (Çakır, 1995; Tekbaş, 2004; Gür, 2006). In vertical enrichment, the number of courses and activities remained the same, but in-depth studies were conducted for the normal students (Çakır, 1995). As a result of the work that Tekbaş (2004) developed and through which he implemented a vertical and horizontal enrichment program for the gifted second year student for 2 years, other students in the class were reported to benefit from the implementation..

In the field literature in the time period (2009-2010) in which this study was conducted, research on gifted children in early childhood and primary education in Turkey was observed to be drawing attention to the need for tools to be used in diagnosis and suggesting the development of tools. It also emphasized the importance of enrichment practices and the need for these practices in meeting the different educational needs of these children (Dağlıoğlu, 1995; 2002; Tekbaş, 2004; Ataman 2004; 2009; Ekinci, 2002).

In studies related to giftedness and early childhood since 2010, when the research was carried out, early intervention suggestions, using multiple methods in diagnosis, increasing differentiation, and processing enrichment practices as educational support, and more experimental studies are recommended (Bakioğlu, \& Levent, 2013; Şahin, 2015; Koç \& Saranl1, 2016; Bildiren, 2016; Pemik \& Levent, 2019). In early childhood diagnosis was conducted using multiple criteria, diagnostic-evaluation, and program implementation with multiple diagnostic tools (Bildiren, 2016; Saranl1, 2017; Saranl1, Er, \& Deniz, 2017) and these studies were conducted directly with children.

Gifted and talented children in Turkey have faced important problems due to limited educational opportunities, developing their talents, and uncovering their abilities. Early and differentiated training is essential to early identification of these children and maximizes their capacities. In all these intelligence areas, it is necessary to diversify the program and reveal the hidden intelligence in children. It is also important to prepare environments in which the five senses will be stimulated to prompt all the intelligence of the child, especially in early childhood (Turnbull et al., 2002; Ataman, 2003; 2009).

For these reasons, the gifted children of the scale to detect early childhood, and their applicability in Turkey, gifted children, which also included their peers in their class, the implementation of multi-intelligence-based enrichment program as a problem is encountered. The literature review indicates that no research was conducted in this context.

In the framework of the main objectives of this study, the first stage was to identify gifted children adapting Brigance K \& 1 screen II to Turkish with a rough evaluation. The second stage to determine the effect of this application on multiple intelligence areas by applying an 
enrichment program to gifted children and classmates determined by screening. For this purpose, this study has the following research questions:

(1) Is the Brigance $\mathrm{K} \& 1$ screen II test a valid and reliable measurement tool for identifying primary school gifted children?

(2) Are the differences between the existing school programs and the enrichment program for gifted and talented children and their classmates attending primary school first grade in favor of the enrichment program?

(3) Is there a difference between pre-test and post-test scores of the enrichment program applied to gifted and talented children and their classmates in favor of the post-test?

(4) Does the enrichment program have an impact on the performances of the multiple intelligences in favor of the enrichment program, applied to the gifted and talented children and their classmates attending primary school first grade?

It is considered that this research will contribute to the identification of gifted children in the early period, support their superior abilities with the enrichment program to reveal and use their hidden potentials, acknowledge their role in the development and ensure the education of children in a sufficient and supportive way and thus be highly beneficial to society.

\section{Method}

\section{Research Model}

The research was conducted with an experimental design in the screening model with a pre-test-post-test application. A screening model is called screening studies, where participants' perceptions related to a subject or activity, or the characteristics of interest, skill, ability, attitude, and so on are generally performed on relatively larger samples compared to other studies (Fraenkel \& Wallen 2006). In an experimental design, the differentiation dimension of the effects of applications performed on two or more groups in terms of certain variables (Fraenkel \& Wallen 2006; Büyüköztürk, 2007b).

\section{The Study Group}

Considering the age group that constitutes the scope of the Brigance K\&I Screen II test, the population of the study consists of first-grade students (over 6 years old) in private and public primary schools in the central districts of Ankara. The study group of the research consisted of gifted children and classmates who were determined by Brigance $\mathrm{K} \& 1$ screen II scale, which was one of the first-grade students attending a private and two public primary schools with a 5\% error margin in the 2008-2009 academic year (Table 1).

\section{Instrument}

Primary school with Brigance K\&1 Screen II test (Brigance kindergarten and first grade screening test), Teele Multiple Intelligence Preference Inventory (TIMI) and "GoodenoughHarris draw-a-person test," were used to determine gifted children in the 1st grade of primary school . The "program enrichment" package program developed by the researcher for the first grade and, enrichment program pre-test-post-test called "I evaluate myself" and "project assignment evaluation criteria list" were the data collection tools.

Brigance K\&1 Screen II Test: It is a screening test adapted to Turkish and used to roughly identify specially gifted children. It was developed by Albert Brigance in 1982 as Brigance K 
\& 1 screen. The test was re-standardized as Brigance K \& 1 screen II in 2005. There are two basic screening forms that include five years old preschool students and six years old primary school first-grade students.

Brigance $\mathrm{K} \& 1$ screen II test can determine whether children are disabled by $81,84 \%$ of children with advanced development, and $84 \%$ of children with typical development. The test consists of 12 subtests in the following three development areas: quantitative perception of subtest (academic field); receptive language, expressive language, articulation, oral expression, and fluency and syntax subtests (communication field); visual, motor, fine motor skills, drawing skills, and gross motor skills subtests (motor field).

Teele Multiple Intelligence Preference Inventory: The Teele inventory of multiple intelligences (TIMI), developed by Sue Tele in 1992 and reviewed for the third time in 1997, is based on Gardner's seven intelligence areas in the field of multiple intelligence. The average application time is 20 minutes. It can be applied individually to small or large groups. The child is asked to choose between two pictures each time. The inventory can be applied between 3 and 65 years of age.

Goodenough-Harris Picture Test: "The human drawing test" developed by Goodenough in 1926, was rearranged by Harris (1963) and was renamed as "Goodenough-Harris draw-a-person test." Goodenough used the terms "mental maturity" or conceptual maturity instead of the term in good intelligence. The test can be applied as a group. Children are given instructions regarding the boots of a man and a woman. The assessment is based on the boys scoring chart consisting of 73 items and the "girl scoring chart," consisting of 71 items. A test feasibility study by Uçman (1971), was conducted by determining 180 subjects randomly in Ankara.

Pre-test and Post-test Called "I am Evaluation My Self" Development: Pre-test and post- test, which was prepared to evaluate the effect of the enrichment program, was developed by taking an expert opinion and pre-application. From two public schools, 1 third grade, 1 second grade and one 4th grade class were determined randomly. The developed test was applied to a total of 18 students, two of them at the lower, middle and upper success levels, according to the class. Due to the inclusion of activities up to the 4th grade in the program, a pre-test was applied to a 4th grade branch of the public school to check the level of the program.

Following the application, the students were asked to evaluate the comprehension of the test and find the easiest answers in terms of information, and the easiest questions. After this application, the test is rearranged. Pre-test- post-test, multiple wits, gifted and expert teachers in the field of enrichment, teachers of the applied classes, first-grade teachers, and consultant faculty reviewed the process. Classroom teachers and teachers of the applied grades discussed the level of questions, comprehensibility, and question type. The researcher also evaluated the level, understandability of the questions and the level of measuring the program with the expert teacher and the advisor. After the arrangements were made, the pre-test was applied to 18 other students from the same classes with the first applied method.

The pre-test and post-test reflecting the enrichment program consisted of 25 questions and 50 answers. Questions are in the form of space completion, multiple choice, table reading, picture description, and make an inference from the picture and shape. Pictures and figures on the worksheets were put on the sides of the questions as a reminder. The pre-test and post-test created from the activities in the Enrichment Program were named as "I am evaluating myself". 


\section{Data Collection}

In the first stage, the data were obtained by applying Brigance K\&I Screen II, Teele Multiple Intelligence Preference Inventory and Goodenough - Harris Picture Test, respectively. This stage will be explained under the title of Study I.

In the second stage, the application and evaluation of the Enrichment Program and the implementation and evaluation of the Project Assignments were carried out. This stage will be explained under the title of Study II. The tests applied to students in three primary schools and information about the enrichment program are given below in a table.

Table 1. The Scales Used in the Research and the Number of Students Applied to the Enrichment Program

\begin{tabular}{|c|c|c|}
\hline Name of applied test & $\begin{array}{l}\text { Number of students } \\
\text { 1st grade }\end{array}$ & $\begin{array}{l}\text { Number of identified } \\
\text { gifted candidates } \\
\text { 1st grade }\end{array}$ \\
\hline Brigance K\&1 Screen II & 477 & 35 \\
\hline $\begin{array}{l}\text { Teele Multiple Intelligence } \\
\text { Inventory }\end{array}$ & 145 & \\
\hline Goodenough-Harris Picture test & 78 & \\
\hline Classwide enrichment program & 379 & \\
\hline Project assignments & 163 & \\
\hline
\end{tabular}

\section{Study I}

In this section, the application process of Brigance K \& 1 Screen II, Teele Multiple Intelligence Preference Inventory and Goodenough - Harris Picture Test, which were applied in the first stage of the research, are explained.

Application of Brigance $K \&$ I Screen II Test: The Brigance test was applied to the whole sample group (477 children) by the researcher individually. The average application time is 30 minutes. After the application, the total scores were calculated according to the directive, and the upper, middle, and subgroups were determined. The test, roughly determining academically successful and gifted children, accepts a total score of 79 and above as the limit score for 6 years old.

Application of Teele Multiple Intelligence Preference Inventory: This inventory was applied individually to $30 \%$ of the sample by the researcher. This group consists of 145 children in total, with students who fall in the upper $20 \%$ score range according to Brigance, children who attract the attention with their different development during the assessment and whom the teacher specifically wants to be evaluated.

Application of Goodenough - Harris Draw-Picture Test: This test was applied to a total of 78 first grade students in the study. According to Brigance, the group consisted of 35 students who were considered gifted and scored 80 and above, and 43 students who were accepted as intermediate and scored between 65 and 79. In practice, the instructions of the test were followed.

\section{Study II}

As the second stage of the research in this section, the process of preparing the enrichment program, the pre-implementation of the program, the pre-tests of the program, the 
application of "I am evaluating myself," the enrichment program control group, the application of the program, the application of the post-tests (I am evaluating myself) and the preparation, implementation, and evaluation of project assignments were explained.

Process of Preparing Enrichment Program: Based on Renzulli's school-wide enrichment, the practice was called class-wide enrichment due to the application of the same model to the whole class because of the research sample's being restricted to the first grade.

For this enrichment program, life sciences guidebooks of 1st, 2nd and 3rd grade prepared by the Ministry of National Education for classroom teachers were taken as basis. Among these books, the subjects of "Seasons", "Weather" and "Night - Day" in the theme "Yesterday - Today - Tomorrow" were determined. Since the topics in the program will be handled in multiple ways, it was decided to prepare the enrichment program only in the "life sciences" course. The program consisted of vertical and horizontal enrichment on the basis of multiple intelligences and activities covering grade 1 - 2 - 3 and 4 levels. Life studies lesson "Seasons", "WeatherWeather Forecasts" and "Night - Day - The World Always Turns" subjects are based on the 3rd grade achievements.

A PowerPoint presentation was used as the material of the program that supports worksheets and course-processing. The activities were formed using various geometric shapes with written explanations, questions, and instructions. Activity-related figures and pictures are included in the worksheets. The letter size used in the study pages was determined as 14 points considering the children's class. Activities support verbal-linguistic, visual spatial, logic-mathematics, internal, social and natural intelligence; creativity, comparison, relational analysis, synthesis, concept map, cause-effect study, shape explanation, and shape completion, analyzing and grouping given information, completing the deficiencies using the provided information and own knowledge, using information to establish a relational analysis between the two situations, transferring information, using their experiences, transferring them to the appropriate situation, reasoning, using imagination, making foresight, creating awareness in daily life events, developing a scientific perspective, drawing, graph reading, chart completion, Venn diagram, and grid study are structured. Bloom's Taxonomy was used in creating the activities and organizing the program.

Preliminary Application of Enrichment Program: After the preparation process of the program, multiple intelligence-based education and enrichment were applied by the application of the program by the classroom teacher in a private elementary school, and the process of the program was examined. The pre-test was applied by the class teacher before the program. The researcher participated in the pre-application process of the program as an observer. The researcher recorded the instructional strategy, implementation period, and response time of the students. Intelligibility and application time and format of the program were determined according to the application in the class. The pre-application teacher has a master's degree in gifted and talented children and specialized in multiple intelligence studies.

The Implementation of the Program: According to Brigance, the enrichment program is to support gifted children in their own classrooms, as well as to identify children who cannot show their real performance in the diagnosis process (with Brigance and Teele), and to determine how well normally developing children benefit from the "enrichment program" in a "coeducational environment", where applications covered all classes.

After the necessary arrangements were made, pre-tests were conducted in two public primary 
schools on April 20-22 and in private primary schools on May 25. The students completed the pre-test in two course hours. Following the implementation of the pre-tests, the implementation of the program started in a parallel manner in two public primary schools on April 28. The researcher was able to assist and guide the teacher in each class during the implementation process of the program and observe it at the same time. The program was implemented in three schools in a total of 13 classes. In each class, the working kit was distributed to the children as well as activities on the worksheet, and the class began to be processed. Subjects were studied with activities entirely. The process of the activities was started with brainstorming and guided by a question-answer, demonstration, and drama methods. In addition, sphere, flashlight, pen, map of the world and Turkey, computer, and projector were used as auxiliary materials in the class.

Posttests were administered in each classroom when the general assessment in the classroom after the Enrichment Program was completed. The students completed the post-test in two hours. This process was implemented in every classroom. Post tests were conducted in May in two public schools and in June in private schools. Students completed the post-test in two lesson hours.

Enrichment Program Control Group: In two public schools, one class from the third grade and one second grade in one school were determined by chance method, and the program was applied by the class teacher after the pre-test was applied to these classes. To illustrate the way of implementation of the program, the application was made for two lesson hours in the second and third grades under the guidance and supervision of the researcher. After the implementation of the program, the post-test was applied. The teachers of these grades, such as first-grade teachers, were also informed about how to implement the program.

\section{Project Assignments}

\section{Preparation}

The enrichment program was implemented to determine what contributes to the development of multiple intelligences in children. The projects consisted of subjects included in the guidance books of the Turkish Ministry of National Education and the subjects covered in the enrichment program and the ones cannot be included in the enrichment program. Sixteen projects were identified, and the sixteenth issue arose from the question a student asked during the program.

\section{Application}

Project assignments were given to 163 students in total. 92 of them are students with high scores from Brigance and Teele, the others (75 students) are students who have a high participation in the enrichment program, who want to be assigned homework and for whom the teacher wants to assign homework.

Each student has chosen a subject and two subjects have been given to the student. Students have submitted their projects in the forms of a file, cardboard, and online presentations. Almost all the students had assignments and presented them in the classroom. Ninety students in seven classes in two public schools submitted their project assignments. 


\section{Evoluation}

Project assignments were evaluated based on creativity and multiple intelligence areas. For this, a 35 item "Project Homework Assessment Criteria List" prepared by the researcher and the consultant and for which expert opinions were obtained was applied. In the preparation of the criteria list, besides the creativity elements, the specific features of the projects were also considered. Almost all of the students in the lower, middle, and upper scores who were assigned homework showed high performance. This is in line with the situation in which students' willingness to take assignments and presentations were observed at high levels. In particular, during the presentation, students effectively used presentation techniques and knowledge transfer from the enrichment program. Most of the students made presentations on the subject. The project assignments of the students were evaluated according to the results of Teele in the field of multiple intelligences.

Children preferred projects numbered 10,9,11 and 16 among the project subjects. These project titles are as follows: 10. Which animals sleep and do not sleep at night? Why don't they sleep at night? 9. What kind of shelter do animals use? Tell me more about the shelter you found. 11. How do people live in homes according to the climate they live in? Why? and 16. How do migratory birds find their way when they migrate, how are they able to stay in the air for a long time, where do they take a break? The least preferred project subjects are the ones numbered 4 and 6. These project titles are: 4. What are the foods stored in canned food? How is it done? 6. Dried stuffed, pickled grape leaves, flour tarhana, etc. what materials are used and how are they made? The preference rates of subjects other than this distribution were close to each other with a high number (9-12).

\section{Data Analysis}

The data obtained in the study were analyzed with the SPSS Statistics package program. In comparing the pre-test-post-test score differences of the groups, t-test for dependent groups, analysis of variance in determining the difference between the groups applied to the program, and in cases where there was a difference, the source of the differentiation was analyzed with the Tukey test.

\section{Findings and Discussion}

\section{Findings Related to Sub-Problems}

\section{The First Sub-Problem}

Is the Brigance $\mathrm{K} \& 1$ screen II scale reliable in identifying gifted and talented children attending primary school first grade? Tables 2 and 3 show the details.

Table 2. Comparison of the Brigance Test with the Goodenough - Harris Draw-a-Person Test in Terms of Reliability in Determining Gifted Children

\begin{tabular}{|c|c|c|c|c|c|c|}
\hline Variables & Group & $\mathbf{n}$ & $\mathbf{X}$ & $\mathbf{S}$ & $\mathbf{t}$ & $\mathbf{P}$ \\
\hline \multirow[t]{2}{*}{ BRIGANCE } & Upper group & 31 & 84,22 & 3,42 & \multirow{2}{*}{12,584} & \multirow{2}{*}{0,000} \\
\hline & Medium group & 35 & 72,23 & 4,21 & & \\
\hline \multirow[t]{2}{*}{ G-HARRIS } & Upper group & 31 & 125,45 & 5,84 & \multirow{2}{*}{7,286} & \multirow{2}{*}{0,000} \\
\hline & Medium group & 35 & 107,60 & 12,48 & & \\
\hline
\end{tabular}

According to Table 2, the Goondenough-Harris scores of the students with the upper tranche 
are also in the upper tranche. As Table 2 depicts, Brigance score average of the students in the upper group was 84.23, while Goodenough - Harris draw-a-person test score average was 125.45. Brigance score average of children in the middle group was 72.23, while GoodenoughHarris draw-a-person test score average was 107.60. According to Brigance test results, the scores of the students in the upper group received from the "enrichment program, " and the "project homework" assessment scores are in the upper group compared to the other students'. The findings of the study revealed that Brigance K\&I screen II is effective and reliable in identifying children with special abilities.

Table 3. The Relationship Between Pre -Test Post-Test Scores and Brigance Scores of the Enrichment Program Applied to Children in Primary First Grade

Correlations between test scores $(n=379)$

\begin{tabular}{lll}
\hline Tests & Post- test & Brigance \\
\hline Pre-test & $.51^{* *}$ & .54 \\
Post-test & & .53 \\
\hline
\end{tabular}

A positive and significant relationship between the pre-test and post-test scores of the students ( $r=.51, p<.01$ has been observed). There is also a positive and significant relationship between students' pre-test and Brigance scores (.54). This result shows that the higher the pre-test scores, the higher the Brigance scores. Similarly, a positive, moderate and significant correlation between the students' post-test scores and the Brigance scores $(r=.53, p<.01)$ was found. These findings were evaluated using pre-test and students' readiness of the enrichment program prepared based on multiple intelligences and Bloom's Taxonomy on Life Science course subjects, and their latencies were evaluated with the post-test. In other words, the points they obtained in the enrichment program, which is parallel with the students' Brigance scores, evaluated them correctly and enabled them to achieve success in line with their own abilities and abilities. The parallelism between two different assessment tools ensures that students are evaluated correctly.

\section{Second Sub-Problem}

Is the enrichment program applied to gifted children attending the first grade of primary school and their classmates different from the existing school programs in favor of the enrichment program?

Table 4. Comparing the Achievement Scores of Second Grade and Third-grade Students with Gifted

\begin{tabular}{lllrllll}
\hline & Group & $\mathrm{n}$ & $\overline{\mathrm{X}}$ & $\mathrm{S}$ & $\mathrm{F}$ & $\mathrm{p}$ & Source of differentiation \\
\hline 1. & Gifted & 31 & 18.77 & 7.68 & & & \\
2. & $2^{\text {nd }}$ grade & 34 & 7.00 & 5.35 & 36.10 & .000 & $(1-2,1-3)$ \\
3. & $3^{\text {rd }}$ grade & 51 & 8.31 & 5.52 & & & \\
& Total & 116 & 10.72 & 7.81 & & & \\
\hline
\end{tabular}

According to the descriptive data presented in Table 5, the average achievement score of firstgrade students is 18.77, while the average of the second-grade students with normal development is 7.00 and the average of this value for the third-grade students is 8.31 . According to these results, the scores of gifted first-year students showed a statistically significant difference according to the second and third-grade students with normal development and were taken as the control group in the program $(\mathrm{F}=36.10, \mathrm{p}<.01)$. In the first grades, the entire enrichment program implementation was carried out under the observation and guidance of the 
researcher. The implementation of the program in the second and third grades is left to the control of the classroom teacher. As an example, the researcher applied the program by entering two lesson hours in the second grade and two hours in the third grades. In addition, he gave the classroom teachers a sample of the program, along with the program implementation instructions, and informed them verbally. Despite all this, the application in the second and third grades was beyond the control of the researcher. The findings of the study by Little et al. (2007) are in line with the findings of this study presented in Table 4.

\section{Third Sub-Problem}

Is There a Difference in Favor of Post-Test Scores between the Pre-Test and Post-Test Scores of the Enrichment Program Applied to Gifted Children and Classmates Attending Primary School 1st Grade? This question is answered in Table 5-7.

Table 5. t-Test Results for The Difference Between Pre-test and Post-test Scores for Enrichment Program of Primary School First-Grade Gifted Students (Brigance Upper Group)

\begin{tabular}{llllll}
\hline Tests & $n$ & $\bar{X}$ & $S$ & $t$ & $p$ \\
\hline Pre - test & 31 & 17.87 & 6.28 & & \multirow{2}{*}{-13.75} \\
Post - test & 31 & 36.71 & 5.75 & .000 \\
\hline
\end{tabular}

According to Table 5, a statistically significant difference between the pre-test scores of the first-grade gifted students before the enrichment program and the post-program post-test scores $(t=-13.75, p<.01)$ has been observed. While the students' mean score before the enrichment program was 17.87 , this value increased to 36.71 in the post-test mean scores obtained after the enrichment program. This finding shows that the enrichment program applied to the students' life science lesson is effective. In addition, a positive and significant relationship between pretest and post-test scores was found. According to this finding, gifted students showed targeted development by benefiting from the enrichment program at a high rate. One of the most common and effective methods used in the education of gifted students is the various types of enrichment (vertical-horizontal enrichment, enrichment clusters, enrichment classes, enrichment resource rooms/centers, class retrieval/pull-out, school-wide enrichment, and enrichment triad). The findings of several studies conducted in primary education in different years are in line with the findings of this study presented in Table 5. Table 4 depicts the findings of the study on the talent groupings of Kulik (1992), Reis, Westberg, Kulikowich, \& Purcell (1998)'s curriculum compression and enrichment, VanTassel-Baska, Zuo, Avery, and Little (2002)'s use of advanced content, Morgan (2007)'s enrichment clusters and, Field's (2009), Renzulli's based on the triple enrichment model the results of the studies are in parallel with the findings of this study.

Table 6. Primary School Students Brigance-Intermediate Group Enrichment Program Pre-test and Post-test Scores for the Difference t-Test Results

\begin{tabular}{llllll}
\hline Tests & $n$ & $\overline{\mathrm{X}}$ & $S$ & $t$ & $p$ \\
\hline Pre - test & 35 & 15.74 & 6.43 & \multirow{2}{*}{-12.86} & \multirow{2}{*}{.000} \\
Post - test & 35 & 31.83 & 6.78 & & \\
\hline
\end{tabular}

According to Table 6, a significant difference between first-grade students who got intermediate scores according to Brigance $\mathrm{K} \&$ I screen II, between pre-test scores of the enrichment program, and post-test scores $(t=-12.86, p<.01)$ was found. The mean score of the students increased from 15.74 to 31.83 after the enrichment program. There was a moderate, positive, and significant relationship between pre-test and post-test scores. This finding shows that success has been achieved by having a high level of participation in the program, which cannot 
be included in the gifted group due to border points. The enrichment program was used as a second assessment tool to capture students who were defended at the beginning section of the current study and scored less for any reason than their available status and potential in the screening test. Sources (Ataman, 1976, 1984, 2003, 2004, 2009; Moon \& Rosselli, 2002; Hallahan \& Kauffman, 2003; Reis \& Renzulli, 2009), identifying gifted students correctly or students are eligible for an appropriate training program propose multiple criteria for referral.

In addition, the purpose of implementing the enrichment program throughout the class is to develop students' skills except the gifted students using multi-intelligence enrichment. This finding supports both the multicritical assessment and other research findings that the beneficiation of non-discriminating enrichment applied is beneficial to other students, except for gifted students; Gentry and Owen's (1999) cluster groupings and instructional grouping with differentiated teaching and content, Kulik's (1992) talent/instructional groupings, Reis et al's., (2007); Reis, Eckert, McCoach, Jacobs and Coyne's (2008) Schoolwide Enrichment Model-Revised application studies support the research findings presented in Table 4. As a result of these studies, the students who missed the score limit for the average level of successful or gifted students had a high level of success as a result of the study when they were included in an application or program with gifted students.

Table 7. Primary School Students Brigance-Below Average Group Enrichment Program Pretest and Post-test Scores for the Difference t-Test Results

\begin{tabular}{llllll}
\hline Tests & $n$ & $\bar{X}$ & $S$ & $t$ & $p$ \\
\hline Pre - test & 312 & 9.25 & 4.85 & & \\
Post - test & 312 & 25.43 & 8.68 & -36.12 & .000 \\
\hline
\end{tabular}

According to Table 7, a statistically significant difference between first-grade students who got below-average scores according to Brigance K \& I screen II, between pre-test scores of the enrichment program and post-test scores $(t=-36.12, p<.01)$ has been observed. While the mean score of the students before the enrichment program was 9.25, this value increased to 25.43 after the enrichment program. Although the students in this group received lower scores than the screening test, they showed the effect of class-wide enrichment in the enrichment program, such as two groups at the highest level, which would make a significant difference from the program (Reis et al., 2007; Reis, Eckert, Mc Coach, Jacobs, \& Coyne, 2008). The difference between the pre-test average and the post-test average is also a point to be considered. In this group, although it is assumed that there will be some gifted and talented students who score lower than the screening test for any reason, the results showed that all children benefit from the multi-intelligence enrichment program at a high level. The enrichment program is considered to be effective in achieving high achievement in Brigance students with low scores, such as multiple intelligence, Bloom taxonomy, vertical and horizontal enrichment, development of different perspectives, generalization of acquired knowledge, and continuous interest.

Transferring knowledge to children through different methods and using different thinking methods, as well as using various methods to learn about the knowledge, skills, and abilities of children have surprisingly positive results. This gives positive results not only for gifted children but also for all children. This result means that students should be evaluated with multiple criteria (Ataman, 1976,1984, 2003, 2004, 2009; Moon \& Rosselli, 2002; Hallahan \& Kauffman, 2003) and that gifted students should be included in enriched teaching in the same classroom environment as their peers have a high level of support in the relevant literature. 
Kulik (1992); Gentry and Owen (1999); Reis et al., (2007); Reis, Eckert, Mc Coach, Jacobs, and Coyne (2008) reported that various enrichment practices performed by students of all achievement levels (upper, middle, and low) showed different levels of success.

Table 8. One-way Analysis of Variance (ANOVA) Results for the Difference in the Achievement Scores of the Gifted, Average, Below-Average Students

\begin{tabular}{lrllll}
\hline Source of Variance & \multicolumn{1}{c}{ SS } & df & MS & F & p \\
Between groups & 204.21 & 2 & 102.11 & 1.66 & .191 \\
Within groups & 23060.93 & 375 & 61.50 & & \\
Total & 23265.14 & 377 & & & \\
\hline
\end{tabular}

Table 8 depicts that there was no significant difference between the achievement scores of the gifted, average, and below-average students $(F=1.66, p>.05)$. In other words, the achievement scores of the students in terms of the difference between the post-test and pre-test scores of the students did not differ by the below average, high, or average ability of the students. Colangelo et al., (2004) and Rogers' (1991) enrichment learning has been found useful for students at all levels of achievement. Little's (2007) effect of curriculum regulation in social sciences did not show any significant difference in the small sub-sample of gifted children.

\section{Fourth Sub-Problem}

Is the Effect of the Enrichment Program applied to Gifted Children and Classmates in the 1st Grade of Primary Education on their Performance in Multiple Intelligence Areas in favor of the Enrichment Program? This question was answered with the results of Teele Multiple Intelligence Preference Inventory and Project Homework Assessment Criteria List.

All gifted and talented children (31 students) participating in the enrichment program had a high level of participation according to their other friends (347 students) during the implementation of the program and had higher scores than the last test of the program. In addition, the students in the gifted and talented group showed a high level of performance in the project assignments given at the end of the program. Project assignments were given to the students with high scores, according to Brigance and who have participated at a high level during the enrichment program. According to Brigance, the students who took the middle and lower level, among the students who took the project, were also included. Thus, the performances of the upper, middle, and sub-groups in project assignments were also compared. Project assignments are evaluated with a list of 35 items that take into account creativity and multiple intelligence areas. After this evaluation, students' assignments, the areas previously concentrated on the application of TIMI, were compared with the scores obtained as a result of the project evaluation. As a result, it has been determined that there is development in the multiintelligence areas of gifted and talented children participating in the program and receiving project assignments. Beyond the overlap between the score distribution in project assignments and the scores taken in TIMI, it was also determined that the trend in the lower area has increased.

According to Brigance, apart from the students in the upper group, the students who participated in the enrichment program and who took the project homework, and who were in the middle and sub-groups, showed similar improvements. The positive effects of the enrichment program were seen in all students' project assignments. In the projects, information, pictures, content, forms, fluency, and message have been transferred from the program. They are not in the form of pure transfer from the program but shaped according to the nature of the homework subject. Transferring the information according to its own level, if the subject is narrated by the picture, 
such as finding/creating and placing appropriate pictures, the tool is used to transfer the information. The enrichment program enables gifted and talented children to improve their performance in multiple intelligence areas.

This situation was observed during the program process and identified in both the post-test scores, as well as in the project assignments presentations and evaluations. From the beginning of the academic year when the research was conducted, the researcher was in constant communication with the school, students, and teachers until the end of the second semester, when the program was implemented, and project presentations were made. During this period, approximately a month after the completion of the enrichment program, the teachers received feedback from the students about the transfer of the knowledge and behaviors they acquired from the program to the other courses they used in the classroom and reflected on their games. This is important for the effectiveness and permanence of the program. With the enrichment program, Renzulli's SEM was conducted. In addition to the improvement of the whole group, $15 \%-20 \%$ of the students benefited from the program through screening and trend determination test. The application of the enrichment program to all first grades has enabled students with low screening test scores to be included in the application and benefit from the program.

\section{Conclusion and Recommendations}

In the study, the effect of enrichment applied to gifted children and classmates determined in 1st grade with Brigance K\&I Screen II on increasing the performance levels of students in multiple intelligence areas was investigated. In the research screening model, pretest-post-test was applied with experimental design.

The research was carried out within the framework of four sub-problems and the findings obtained were interpreted within this framework. Below are the results obtained according to the sub-problems.

\section{Results Regarding the First Sub-Problem}

Students who scored higher on the Brigance K\&1 screen II also scored higher on the Goodenough-Harris draw-a-person test. Students in group 3 scored higher than their peers in the pre-test applied prior to the enrichment program prepared at the class level. During the implementation of the enrichment program, these students participated in the program at a high level. After the implementation of the enrichment program, they received a high score from the post-test compared to their peers. Students who have been identified as gifted and talented, according to Brigance, have performed in the preparation and presentation of the project papers given after the implementation of the program. These findings reveal that Brigance $\mathrm{K} \& 1$ screen II is effective in identifying gifted and talented students.

\section{Results on the Second Sub-Problem}

The enrichment program applied to gifted and talented first-grade students of primary school in the same environment with their normally developing peers differs from the current school program. The program is created on the basis of multiple intelligence and consists of enrichment activities. In the implementation of the enrichment program, contrary to the traditional method in which the students are passive and teachers are active, question-answer, brainstorming, drama, animation, and demonstration methods were mainly used and the information was attempted to be given with a more verbal expression technique. The Turkish Ministry of National Education Teachers' Guidebooks have been prepared on the basis of 
multiple intelligence, but this could not be fully implemented. For this reason, the enrichment program has been an application in which the students have taken active roles and thus have gained permanent knowledge.

\section{Results on the Third Sub-Problem}

The findings of the study revealed a difference between the pre-test and post-test scores of the enrichment program applied to gifted and talented first-grade students of primary school. With enrichment activities prepared at the third-grade level, students achieved a high degree of difference from the application. A statistically significant difference was achieved between the pre-test and post-test scores of all students included in the program.

\section{Results on the Fourth Sub-Problem}

The enrichment program applied to gifted and talented first-grade students at the primary school increased the performance of students in multiple intelligence areas. Implemented as a class wide enrichment, the program has also made a difference in multiple intelligence areas of other students. As a result, it would be safe to say that tool development is necessary for the early detection of gifted and talented children and these children should be supported in their talented areas. The importance of the use of multiple tools in identifying gifted and talented children is emphasized once again. These children develop more rapidly compared to their peers. The findings of the study show the benefits of being included in teaching in the same environment as their peers. "Class-wide Enrichment" the new practice of the Turkish Ministry of National Education based on multiple intelligences in teaching has been used as a viable model within the structuralist approach. The results reveal that the enrichment application has the potential to be successful. In addition, educational problems of gifted and talented students have been largely solved. The enrichment application was implemented by eliminating applications such as talent groups and enrichment clusters.

\section{Scope and Limitations}

Working group of the research, the Turkey Statistical Institute (TSI) in Ankara central districts representing the middle and upper socio-economic levels, according to 2007 data was conducted in schools in Cankaya district. The working group formed full and part-time schools in this district from private and public primary schools with 1000 or more students. The screening was initially performed in the preschool (five years) and first grade (six years) students, but only 22 students in the preschool (five years) were screened successfully, and thus the enrichment program was applied to the first-grade students only. A pre-test -post-test was used to measure the effectiveness of the program. As the enrichment program was applied to all first-grade students, the control group was not formed from the first graders. The empty control group was created involving second graders and a third graders. To determine the level of the program, a branch in fourth grade was implemented after the program was prepared. The private primary school within the scope of the research is the school attended by the children of families in the upper SED. In addition to the fact that this school has better physical space, equipment and rich teaching materials compared to public schools, it is important for the research that the number of students in the classroom (16) is very low compared to public schools (38).

\section{Directions for Future Studies}

This section includes recommendations and directions to help future research. 
(1) Brigance $K \& 1$ screen II test gifted and talented children will contribute to meeting more to work with children, and Turkey needs instruments in the area where standardization for widespread use in the researcher's expertise area, can be of use for elementary school first-grades.

(2) In order to benefit from the potential of gifted and talented children, it is important to increase class enrichment program applications to the whole class.

(3) new research implementing the enrichment program based on multiple intelligence is important in terms of supporting children in areas where they are talented and revealing their potential.

(4) The preparation of the enrichment programs to be applied in future studies by associating them with other courses can increase the effect of the application and provide higher success.

(5) Class-wide enrichment practice can be performed in different grades and socioeconomic status. In addition, teamwork is required in a triple study, including multiple criteria diagnostics, program implementation, and project work. It is difficult to conduct this with a single researcher.

(6) More effective implementation of the enrichment program points to the training of teachers, the regulation of the environment, and lesser number of students.

\section{References}

Ataman, A. (1976). Educational problems of gifted students. (Unpublished doctoral dissertation). Ankara University, Institute of Educational Sciences.

Ataman, A. (1984). Ankara ili resmi şehir ilkokullarındaki üstün yetenekli çocukların fiziksel gelişim özelliklerinin değerlendirilmesi.[Evaluation of the physical development characteristics of gifted children in official city primary schools in Ankara province]. Ankara University Faculty of Education Sciences.

Ataman, A. (2003/2009). Özel gereksinimli çocuklar ve özel ĕgitime giriş [Children with special needs and entrance to special education]. In. Ataman, A. (Ed.). Gündüz Education and Publishing, Ankara.

Ataman, A. (2004). Gifted and talented children. 1. Türkiye üstün yetenekliler kongresi yayın dizisi 1, seçilmiş makaleler kitabı [1. Turkey sequence broadcast congress gifted 1, selected articles book]. (p.155-168). Children's Foundation Publishing, İstanbul.

Ataman, A. (2004a). A model applicable in education for gifted people. 1. Türkiye üstün yetenekliler kongresi yayın dizisi 1, seçilmiş makaleler kitabı [1. Turkey sequence broadcast congress gifted 1, selected articles book]. (p.335-342). Children's Foundation Publishing, İstanbul.

Bildiren, A. (2016). The effect of project-based approach in early intervention programme on problem solving ability of gifted children. (Unpublished doctoral dissertation). Ankara University, Educational Sciences Institute.

Brumbaugh, E. (1994). An investigation of the implementation of the collaboration consultation modela as a service delivery option for gifted 1st-6th grade students. West Virginia University,184 pages; AAT 9427954.

Büyüköztürk, Ş. (2007b). Deneysel desenler: Öntest-sontest kontrol gruplu desen ve SPSS uygulamalı veri analizi [Experimental designs: Pre-test-post-test control group design and SPSS applied data analysis]. (Improved 2nd ed.). Pegem Academy Publishing, Ankara.

Bakioğlu, A. \& Levent, F. (2013). Recommendations for the education of gifted outstanding Turkey. Journal of Gifted Education Research, 1(1), 31-44. 
Culatta R. A.- Tompkins J. R. (1999). Fundamentals of special education. Exceptional Children (Sixth edition). Ohaio: Prentice Hall New Jersey Columbus,

Colangelo, N., Assouline, S., \& Gross, M. (Eds). (2004). A nation deceived: How schools hold back America's brightest students. Iowa City, IA: The University of Iowa. https://files.eric.ed.gov/fulltext/ED535137.pdf. 06.02.2021.

Cutts, N.E. \& Moseley, N. (2001). Üstün zekâlı ve yetenekli çocukların eğitimi [Education of gifted and talented children]. (İ. Ersevim, Transl.). Özgür Publishing, İstanbul.

Çakır, A. (1995). Gifted and talented children and their education. Modern Education, (20), 215-227.

Davasligil, Ü. (1995). Education of gifted children. Journal of Education for Life, (43), 21 -27.

Davaslıgil, Ü. (2004). Erken çocuklukta üstün zekâlı çocuklara uygulanacak farklılaşmış eğitim program1. 1. Türkiye üstün yetenekliler kongresi yayın dizisi 1, seçilmiş makaleler kitabı [1. Turkey sequence broadcast congress gifted 1, selected articles book]. (p.125-142). Children's Foundation Publishing, İstanbul.

Dağlıoğlu, E. (1995). Identify the gifted children through the grades 2-5 in the elementary schools. (Unpublished master's thesis). Hacettepe University, Health Sciences Institute.

Dağlığlu, E. (2002). The identification of mathematically gifted children among five-six years old preschool children. (Unpublished doctoral dissertation). Hacettepe University, Health Sciences Institute.

Enç, M. (2004). Justification for special education. 1. Türkiye üstün yetenekliler kongresi yayın dizisi 1, seçilmiş makaleler kitabl [1. Turkey broadcast series congress gifted 1, selected articles book]. Children's Foundation Publishing, İstanbul.

Enç, M. (2005). Üstün beyin gücü [Superior brain power]. Gündüz Education and Publishing, Ankara.

Ekinci, A. (2002). Evaluation of teachers' views on the eligibility of primary schools for the education of gifted children. (Unpublished master's thesis). Dicle University, Social Sciences Institute.

Fraenkel, J.R. \& Wallen, N.E (2006) How to design and evaluate research in education 6th ed. McGraw-Hill.

Field, G. B. (2009). The effects of using Renzulli learning on student achievement: an investigation of internet technology on reading fluency, comprehension, and social studies. International Journal of Emerging Technology, 4, 29-39.

Gentry, M. L., \& Owen, S. V. (1999). An investigation of the effects of total school flexible cluster grouping on identification, achievement, and classroom practices. Gifted Child Quarterly, 43, 224-243.

Gür, Ç. (2006) The effect of the art education program on the drawing skills of six-year-old gifted children from upper socio-economic backgrounds. (Unpublished Doctoral Thesis). Gazi University Institute of Educational Sciences.

Hallahan, D.P. \& Kaufman, J., M. (2003). Exceptional learners: Introduction to special education. 9th ed. Allyn and Bacon- Hays/Monkmeyer.

Heward, W., L. (2000). Exceptional children. 8th ed. Prentice-Hall Upper Saddle River.

Kulik, J. A. (1992). An analysis of the research on ability grouping: Historical and contemporary perspectives (RBDM 9204). Storrs, CT: The National Research Center on the Gifted and Talented, University of Connecticut. https://nrcgt.uconn.edu/wpcontent/uploads/sites/953/2015/04/rbdm9204.pdf

Koç, F. \& Saranl1, A. G. (2016). Early childhood gifted related multidimensional analysis of graduate studies in Turkey. Mehmet Akif Ersoy University Journal of Education Faculty, (41), 163-183. 
Kadioğlu A., H. \& Afat, N. (2018). A Case study investigating the language development process, early literacy experiences and educational problems of a gifted child. Journal for the Education of Gifted Young Scientists, 6(4), 36-71. http://dx.doi.org/10.17478/JEGYS.2018.83.

Little, C. A., Feng, A. X., VanTassel-Baska, J., Rogers, K. B., \& Avery, L. D. (2007). A study of curriculum effectiveness in social studies. Gifted Child Quarterly, 51(3), 272-284.

Moon, S., M. \& Roselli, H., C. (2002). Developing gifted programs. International handbook of giftedness and talent. Heller, K., A., Mönks, F., J., Stenberg, R., J., \&Subotnik, R., F. (Eds). U.K.: British Library.

Moore, A., D. (1992). Exceptionalities in children and youth. Bullock, L., M. (Ed.). USA: Allyn and Bacon- Hays/Monkmeyer Press.

Morgan, A. (2007). Experiences of a gifted and talented enrichment cluster for pupils aged five to seven. British Journal of Special Education. 34(3),144-153.

Pemik, K., \& Levent, F. (2019). Opinions of school administrators and teachers regarding education in the support room for gifted students. Ankara University Faculty of Educational Sciences Special Education Journal, 20(2), 313-338. http://doi.org./10.21565/ozelegitimdergisi.446598.

Reis, S. M., Westberg, K. L., Kulikowich, J. M. \& Purcell, J.H. (1998). Is there still a need for gifted education? an examination of current research. Learning and Individual Differences. ScienceDirect Web: www.elsevier.com/locate/lindif. 2009.10012.

Reis, S. M., McCoach, D. B., Coyne, M., Schreiber, F. J., Eckert, R. D., \& Gubbins, E. J. (2007). Using planned enrichment strategies with direct instruction to improve reading fluency, comprehension, and attitude toward reading: an evidence-based study. The Elementary School Journal. 108, 3-24.

Reis, Eckert, McCoach, Jacobs \& Coyne, 2008), Is there still a need for gifted education? An examination of current research. Learning and Individual Differences. ScienceDirect. www.elsevier.com/locate/lindif. 2009.10012.

Renzulli, J., S. and Reis, S., M. (2002). The schoolwide enrichment model. International handbook of giftedness and talent. Heller, K., A., Mönks, F., J., Stenberg, R., J., Subotnik, R., F. (Eds.). U.K: British Library.

Rogers, K. B. (1991). The relationship of grouping practices to the education of the gifted and talented learner (RBDM 9102). Storrs, CT: The National Research Center on the Gifted and Talented, University of Connecticut. https://nrcgt.uconn.edu/wpcontent/uploads/sites/953/2015/04/rbdm9102.pdf. 06.02.2021.

Saranl1, A.G., Er, S. \& Deniz, K. Z., (2017). Analysis of language development of gifted children in preschool period. Journal of Education for Life, 31(1), 1-20.

Saranl1, A. (2017). A different view of early intervention practices in preschool period: early enrichment for gifted children. Education and Science, 42(190), 343-359.

Smutny, J., F., Walker, S., Y. \& Meckstroth, E., A. (1997). Teaching young gifted children in the regular classroom. Lisovskis, M. (Ed.). Free Spirit.

Selçuk, Z., Kayılı, H. \& Okut, L. (2002). Çoklu zekâ uygulamaları [Multiple intelligence applications]. Nobel \& Atlas, Ankara.

Şahin, A. (1996). Superior talent and education. Journal of Education for Life, 47, 5-9.

Şahin, F. (2015) A research on the structure of intelligence and creativity, and creativity style. Turkish Journal of Giftedness and Education. 5(1), 2-20

Tekbaş, D. (2004) An analysis of a sample incident on the enriched programme applied to a gifted child in a mainstreaming environment and a research on the efficiency of the programme. (Unpublished master's thesis). Gazi University, Educational Sciences Institute. 
Turnbull, R., Turnbull, A., Shank, M., Smith, \& S., Leal, D. (2002). Exceptional lives (3rd ed.). Merril Prentice Hall.

Witte, S. (1994). An exemplary scope and sequence for gifted children, kindergarten through fifth grade. Columbia University Teachers College. AAT 9511082

Walker, B., Hafenstein, N., L. And Crow-Enslow, L. (1999). Meeting the needs of gifted learners in the early childhood classroom. Young Children, 54(1),32-36.

Wheeler, M. J., (2006). A Comparison of school readiness for preschool children with and without disabilities in inclusive environments. D., Teachers College, Columbia University, AAT 3225206. November 17, 2009, http://proquest.umi.com.

Williams, N. C., (2002). The relationship of home environment and kindergarten readiness. D., East Tennessee State University, 2002, AAT 3083445. November 17, 2009, http://proquest.umi.com.

VanTassel-Baska, J., Zuo, L., Avery, L. D., and Little, C. A. (2002). A curriculum study of gifted student learning in the language arts. Gifted Child Quarterly, 46, 30-44. 